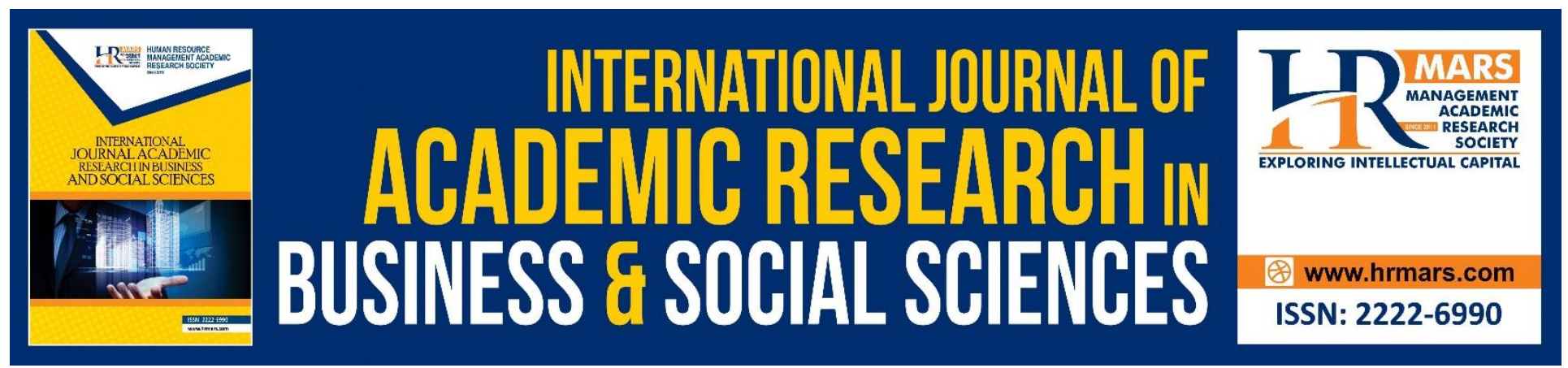

\title{
Does Influence Career Maturity?
}

\section{Siti Raba'ah Hamzah, Ismi Arif Ismail \& Nor Harizan Mohd Zainal}

To Link this Article: http://dx.doi.org/10.6007/IJARBSS/v10-i16/8296

DOI:10.6007/IJARBSS/v10-i16/8296

Received: 03 October 2020, Revised: 28 October 2020, Accepted: 12 November 2020

Published Online: 19 November 2020

In-Text Citation: (Hamzah et al., 2020)

To Cite this Article: Hamzah, S. R., Ismail, I. A., \& Zainal, N. H. M. (2020). Does Influence Career Maturity? International Journal of Academic Research in Business and Social Sciences, 10(16), 120-133.

Copyright: () 2020 The Author(s)

Published by Human Resource Management Academic Research Society (www.hrmars.com)

This article is published under the Creative Commons Attribution (CC BY 4.0) license. Anyone may reproduce, distribute, translate and create derivative works of this article (for both commercial and non-commercial purposes), subject to full attribution to the original publication and authors. The full terms of this license may be seen

at: http://creativecommons.org/licences/by/4.0/legalcode

Special Issue: Youth and Community Wellbeing: Issues, Challenges and Opportunities for Empowerment V2, 2020, Pg. 120 - 133

http://hrmars.com/index.php/pages/detail/IJARBSS

JOURNAL HOMEPAGE

Full Terms \& Conditions of access and use can be found at http://hrmars.com/index.php/pages/detail/publication-ethics 


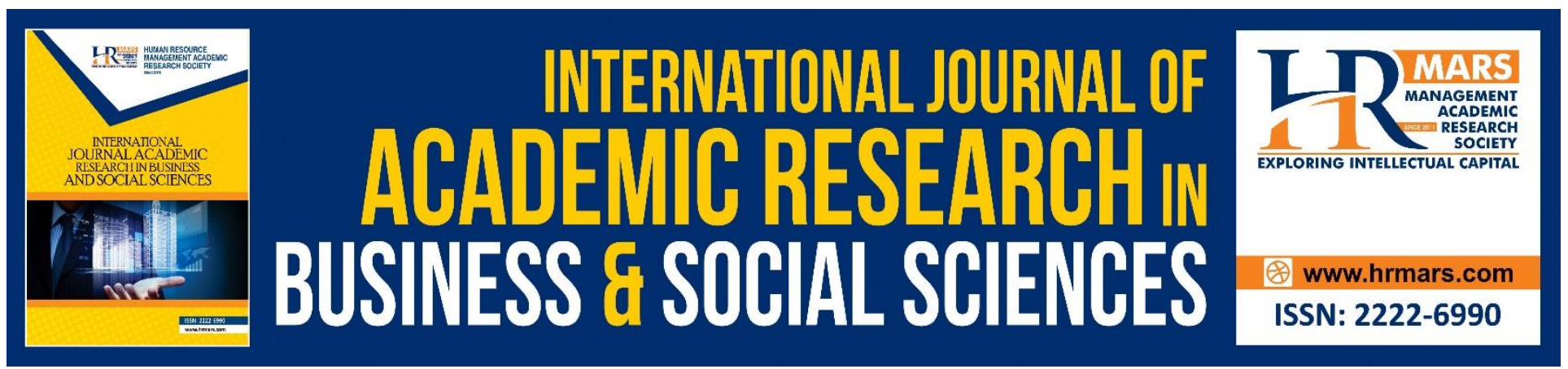

\title{
Does Influence Career Maturity?
}

\author{
Siti Raba'ah Hamzah ${ }^{1,2}$, Ismi Arif Ismail ${ }^{1,2} \&$ Nor Harizan Mohd \\ Zainal $^{2}$ \\ ${ }^{1}$ Institute for Social Science Studies, Universiti Putra Malaysia, 43400 UPM, Serdang, Selangor, \\ Malaysia, ${ }^{2}$ Department of Professional Development and Continuing Education, Faculty of \\ Educational Studies, Universiti Putra Malaysia, 43400 UPM, Serdang, Selangor, Malaysia. \\ Email: srh@upm.edu.my, ismi@upm.edu.my, norharizan2111@gmail.com
}

\begin{abstract}
The purpose of this study was to investigate the influence of volunteer engagement and self-efficacy on the career maturity of young leaders who were members of the Supreme Student Council in a Malaysian university. A cross-sectional study was conducted with data collected via a questionnaire survey. There were 400 respondents, of whom 143 were males and 257 females between the ages of 20 and 25 ( $M$ age $=22.8, S D=5.65)$. The research instrument was a self-administered questionnaire covering volunteer engagement, self-efficacy and career maturity. This study found that the level of volunteer engagement was high $(M=4.25, S D=0.42$ on a scale of 5$)$. The level of selfefficacy among young leaders was similarly high $(M=4.19, S D=0.52)$, whereas the level for career maturity was moderate ( $(M=3.41, S D=0.53)$. A positive relationship was found to exist between volunteering engagement and career maturity $(r=.277, p=.001)$ while the second relationship was between self-efficacy and career maturity $(r=.311, p=.001)$. Both volunteer engagement $(\beta=0.151$, $p<0.05)$ and self-efficacy $(\beta=0.228, p<0.05)$ had significant independent effects on the level of career maturity. Volunteer engagement and self-efficacy together explained $11 \%$ of the variance in career maturity among the young leaders.
\end{abstract}

Keywords: Volunteer Engagement, Self-Efficacy, Career Maturity, Young Leaders

\section{Introduction}

In today's very competitive labor market, higher education institutions play a very essential role in helping undergraduates prepare for their career development and to enhance their employability (Abd Majid et al., 2020; Tang, 2019). Students should be able to identify their capabilities to major in their respective fields of interest so that they might have successful careers upon graduation (Raty et al., 2018; Crebert et al., 2004). However, preparing graduates for the world of work is difficult. At the heart of career development is personal growth, and when actively included the self-efficacy and volunteer engagement, it can assist employability (McKenzie, Coldwell-Neilson and Palmer, 2018). In addition, a major motivator for young people to engage in volunteering programs is the opportunity 
INTERNATIONAL JOURNAL OF ACADEMIC RESEARCH IN BUSINESS AND SOCIAL SCIENCES

Vol. 10, No. 16, Youth and Community Wellbeing: Issues, Challenges and Opportunities for Empowerment V2. 2020, E-ISSN: 2222-6990 @) 2020 HRMARS

to gain work-related experience, skills and qualifications which can help them in their educations and career development (Eley, 2003).

\section{Background and the Context of the Study}

Young leaders are often marginalized from society's organizational power structures. As such, they seldom have the opportunity to experience leadership in the organizations that are designed around their needs and interests. One way to engage young leaders, especially those in the university, is to encourage them to be actively involved in volunteering activities, such as serving in the university Supreme Student Council. Engaging with programs organized by the university may not seem like a typical approach to leadership development, but it has been recognized as an effective alternative channel to develop leadership skills among young leaders. The concept of developing young leaders through volunteering activities involves identifying committee members in the Supreme Student Council to be groomed as future leaders and according them the opportunity to lead the university community.

Volunteering can enhance personal skill development, a sense of civic responsibility, career choice and employability (Hamzah et al., 2016; Hall et al., 2009; Musick \& Wilson, 2008). Studies have also identified volunteering programs that maximize benefits, especially to young volunteers themselves (Shier, Larsen-Halikowski, and Gouthro, 2020; Triantafyllia \& Katerina, 2015). According to Miller et al., (2002) these include activities that provide opportunities for: 1) youth autonomy and decisionmaking; 2) collaborative work with youth and adults; 3) reflection; 4) psychological engagement; and 4) building competence, confidence, character, connection and a caring attitude. Volunteer engagement also helps volunteers themselves to learn new skills and gain experience that may contribute to career maturity.

Self-efficacy is the individual's perception about his capability to manipulate his own level of functioning and other events in his life (Caldwell and Hayes, 2016; Bandura, 2010; 1993). It influences how he thinks, feels, motivates himself, and generally how he behaves. Individuals who are confident about their ability to succeed at a task will perform better than those who are not (Bernard-Phera \& De Bruin 2002). Bandura's self-efficacy theory (1986) confirms that individuals with higher selfefficacy expectations would approach and complete career developmental tasks (as put forward by Super) more efficiently than individuals with low self-efficacy expectations.

Not many studies on volunteer engagement relate it with career maturity. Crites (1971), Super (1977) and Harlow and Bowman (2016) investigated the relationship between self-efficacy and career maturity but their findings showed little evidence that the two were correlated. De Raaf et al. (2009) view the application of Bandura's self-efficacy construct to career development as a very significant contribution to career maturity. In the present study, the researchers combined the variables of volunteer engagement and self-efficacy to measure the level of career maturity among young leaders in a Malaysian university. The researchers believe that the campus years are an ideal time to prepare individuals for the working world, and that the campus is an important place to prepare students for the national and international workforce. During the undergraduate years, students should be given ample opportunities to engage in career exploration with regard to their aptitudes, interests, abilities, 
INTERNATIONAL JOURNAL OF ACADEMIC RESEARCH IN BUSINESS AND SOCIAL SCIENCES

Vol. 10, No. 16, Youth and Community Wellbeing: Issues, Challenges and Opportunities for Empowerment V2. 2020, E-ISSN: $2222-6990$ ๑ 2020 HRMARS

and personalities to make the best or the most appropriate career choices for successful employability in the future (Clements and Kamau, 2018; Beauchamp \& Kiewra, 2004). In other words, undergraduates should be encouraged to engage in a new level of self-awareness and career exploration.

\section{Career Maturity}

Career maturity refers to the readiness to make informed, age-appropriate career decisions when dealing with certain career development tasks (Coertse \& Schepers 2004). Career maturity is defined as "the course of events which constitutes a life; the sequence of occupations and other life roles which combine to express one's commitment to work in his or her total pattern of self-development" (Coertse \& Schepers 2004; Super 1957). Thus, career maturity conceptualizes the readiness of an individual to make an informed choice for a particular career. According to Super (1957) and Crites (1971), such an individual has the ability to: 1) gather information about the self in order to gain occupational insight; 2 ) acquire the necessary skills in order to make an informed career decision; 3 ) integrate self-knowledge and occupational knowledge and 4) implement the abovementioned knowledge when planning for a career. Individuals who have high levels of career maturity would be able to complete more career development tasks successfully in comparison to individuals who have lower levels of career maturity (Birol and Kiralp, 2010; Coertse and Schepers, 2004).

Four global dimensions of career maturity are concern, curiosity, confidence, and consultation. According to Savickas and Porfeli (2011), the concern scale measures the extent to which an individual is oriented to and involved in the process of making career decisions. The curiosity scale measures the extent to which an individual is exploring the working world and seeking information about occupations and their requirements. The confidence scale measures the extent to which an individual has faith in her or his ability to make wise career decisions and realistic occupation choices. The consultation scale measures the extent to which an individual seeks assistance in career decisionmaking by requesting information or advice from others. All the dimensions provide a good view of the individual's attitudes toward career decision- making and readiness to make occupational choices.

Super's theory of career development proposes five dimensions to determine an individual's career maturity or readiness to make responsible and informed career choices. These dimensions include planfulness, exploration, information, decision-making, and reality orientation (Allison and Cosette 2007). In this theory, planfulness refers to the individual's awareness that it is important to make educational and vocational choices at a particular point in time. The second dimension, exploration, involves questioning. Different resources are used to encourage active participation of the individual self. Various aspects are evaluated, such as relationships with educational instructors, school, friends, family or colleagues at work, attitude towards available resources and being prepared to utilize them. The third dimension is information; it incorporates the collection and processing of information in relation to the world of work, the individual's preferred vocational group and other life-career roles. The fourth dimension is decision-making, which is viewed as the cognitive aspect of career maturity. The goal of decision-making is to ensure that an individual has the ability to apply knowledge and insight to his or her vocational planning and decision-making. The fifth dimension is reality 
orientation. This dimension includes the following aspects: self-knowledge, realism in self and situational assessment, consistency of the vocational role, and references. Hence, as discussed above, the individual with high career maturity has positive attitudes toward his or her readiness to make career choices that are appropriate to age and developmental stage, and has the ability to cope with the demands of the work environment at any given life stage (Crişan, Pavelea and Ghimbuluţ, 2015).

\section{Self-efficacy}

Self-efficacy is a factor affecting one's career maturity. Self-efficacy has an important role in influencing the efforts of a person. Self-efficacy can influence students in choosing their activities including preparing for their careers. Students with low self-efficacy may avoid subjects with many tasks, especially for tasks with many challenges or high difficulty, while students with high selfefficacy have a great desire to work on their tasks (Bandura, 1993). According to Singh and Shukla (2015) there is a positive relationship between self-efficacy with career maturity. The research conducted by Bozgeyikli, Eroglu, and Hamurcu (2009) and Harlow, and Bowman (2016) also shows that self-efficacy has a significant positive relationship with career maturity and with socioeconomic status. The results of previous studies, such as research conducted by Patton and Creed (2001) in Australian students show that one of the factors that is related to even a strong predictor in affecting career maturity is self-efficacy. Self-efficacy is the individual's sense of being able to deal effectively with a particular task (Woolfolk, 2007). In the context of education, self-efficacy refers to the perception the student has about his capability to perform at an expected level in order to achieve a specific goal or milestone. Self-efficacy has been shown to influence academic motivation, learning, and achievement (Broadbent, 2016; Pajares and Schunk, 2001). Self-efficacy also influences how individuals think, feel, and motivate themselves as well as how they behave. Individuals who are confident about their ability to be successful in a task will perform better than those who are not (Bernard-Phera and De Bruin, 2002). There are two essential components of self-efficacy, namely the belief that ability can grow with effort and the belief in own ability to meet specific goals or expectations. In short, self-efficacy can be defined as believing in your ability to accomplish challenging tasks and that your ability can grow with effort (Gaumer Erickson and Noonan, 2016). Bandura's self-efficacy theory (1986) propounds that individuals with higher self-efficacy expectations would approach and complete career developmental tasks (as put forward by Super) more efficiently than those with low self-efficacy expectations.

Hypothesis 1; Self-efficacy has positive relationship on career maturity.

\section{Volunteer Engagement}

Volunteer engagement is defined as the contribution and participation of the individual in any volunteering activity (Shantz, Saksida and Alfes, 2014). It is a form of pro-social behavior that involves a freely chosen decision to commit a sustained amount of time and effort. Moreover, it is aimed at helping another person, group, or cause, typically through a non-profit organization. Students often seek out opportunities to get involved in volunteer activities as a way of gaining new experiences and understanding more about themselves, other people, social issues, or a cause (Holdsworth, 2010). Studies have found that that students report stronger career motivation in countries where admission to universities of preferred choice can be bolstered by the inclusion of volunteering work 
on one's resume (Handy et al., 2010). Studies have also found that young volunteers are motivated by the opportunity to gain work-related experience, skills, and qualifications (Smith, 2010); these are viewed as assets for advancement in their education and career (Eley, 2003). Volunteering could enhance personal skill development, sense of civic responsibility, career choice and employability (Hall et al. 2009, Musick and Wilson, 2008). Young people engaged in volunteering also develop positive social behaviors that could help to reduce risk-taking, and they are better prepared for employment in their transition to responsible adulthood (Stukas, Snyder, and Clary, 2016; Marta and Pozzi, 2008).

Through volunteer engagement, individuals learn new skills and gain new experiences that will benefit their career advancement. Indeed, it is important to note that volunteering can add to the social capital (Wollbaeck and Selle, 2002) as well as human capital (McNamara and Gonzales, 2011). Volunteering activities help expand the circle of professional contacts, durable networks, employment leads and social relationships. Therefore, volunteering enhances not only social capital but also human capital, which includes knowledge, skills, abilities, leadership opportunities and work experience (Forbes and Zampelli, 2014).

Volunteer engagement is one of the main issues in volunteerism that can be conceptualized within the framework of the Social Exchange theory. In order for volunteering efforts to be sustained over time, rewards to volunteers must exceed, or at minimum, balance out the costs (Reamon, 2016). According to the Social Exchange Theory, people will contribute to the degree that they perceive that they are being rewarded (Emerson, 1976). When they perceive an imbalance between contributions and rewards, volunteers are likely to move toward a greater equilibrium. The individual who perceives that rewards for volunteering are imbalanced with contributions is likely to discontinue involvement. The Social Exchange theory describes six types of social rewards, namely personal attraction, social acceptance, social approval, instrumental services, respect/prestige, and compliance/power (Zhu, 2012; Wilson, 2000; Blau, 1964).

Based on the literature, volunteering can serve as a pathway to employment through an increase in one's social capital and human capital (Brown and Ferris, 2007; Wollbaeck and Selle, 2002). The combination of these two important aspects will enhance the volunteers' skills and experience. For the social capital some of the aspect was professional contacts, durable networks, employment leads and social relationship, while for the human capital was knowledge, skills, abilities, leadership opportunities and work experience. Siti Raba'ah et al., (2016) evaluate the factors contributing to youth participation in volunteering activities were the perceived benefits from volunteering, the personal needs or fulfillment of the respondents to volunteer and their personal reasons for volunteering. Their findings showed that the "benefits" included learning to shoulder responsibility, broadening interest, fostering relationships, building teamwork spirit, and encouraging socialization within the community setting. The "need" to volunteer was associated with the desire to unleash leadership potential and improve communication skills. Finally, the "reasons" for volunteering included using leisure time meaningfully, getting new experience, improving confidence and selfesteem, attaining emotional stability, and getting a better understanding of the realities of life. 
Hypothesis 2; Volunteering engagement has positive relationship on career maturity.

This study was aimed at investigating the interrelationship of volunteer engagement, self-efficacy, and career maturity among young leaders in a selected university in Malaysia, specifically (1) to determine the levels of volunteer engagement, self-efficacy, and career maturity among young leaders; 2) to investigate the relationship between volunteer engagement and self-efficacy towards career maturity among young leaders; and 3) to determine the predictors towards career maturity among young leaders. The research framework of this study is as illustrated in Figure 1.

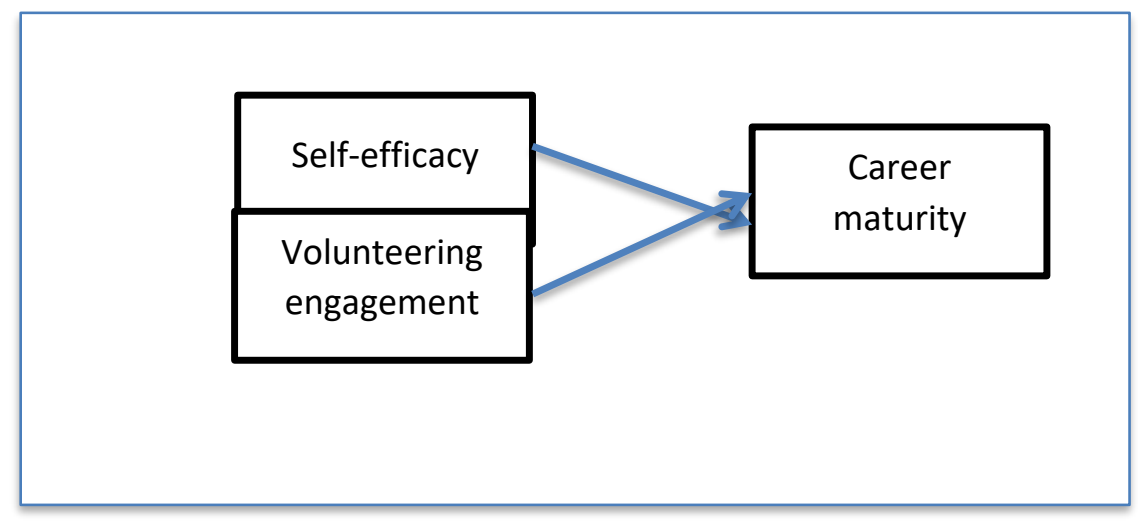

\section{Methodology}

The study used a quantitative approach in which the requisite data were collected from responses to a survey questionnaire. A purposive sampling technique was adopted to determine an appropriate sample. Prior to data collection, preliminary preparations were made, with the principal researcher contacting the respective chairpersons of the Supreme Student Council of 17 residential colleges in Universiti Putra Malaysia, and making appointments to meet with the council members. The researcher administered the questionnaire herself and also assisted the respondents to complete it. The respondents were given $20-30$ minutes to complete all the items in their questionnaire. The data were analyzed using SPSS version 23. Descriptive statistics were used to compare the mean scores for the study variables. Bivariate correlation and regression analyses were employed to test the relationships and to determine the predictors.

In order to meet the objectives of this research, the questionnaire survey solicited information covering three key areas as well as demographics factors. The first section was the demographics item, followed by three sections soliciting information on volunteering engagement, self-efficacy and career maturity. The participants were asked to indicate their response to each item by using a 5point Likert scale ranging from 1 (strongly disagree) to 5 (strongly agree).

The thirty items on volunteering engagement employed in the questionnaire for this study were adopted from a previous study by Raba'ah et al. (2016). Meanwhile, based on a study done by Pajares and Schunk, (2001) and Pajares \& Johnson, (1996) a 12- item measure of the individual's self-efficacy was applied. Examples of the items were: 'I can understand what is being taught in class this year', 'I can figure out anything if I try hard enough' and 'If I practiced every day, I could develop just about any skill'. 
INTERNATIONAL JOURNAL OF ACADEMIC RESEARCH IN BUSINESS AND SOCIAL SCIENCES

Vol. 10, No. 16, Youth and Community Wellbeing: Issues, Challenges and Opportunities for Empowerment V2. 2020, E-ISSN: 2222-6990 @ 2020 HRMARS

The career maturity components were adopted from Crites and Savickas (1995). The 24-item section measures career maturity that was divided into sections representing 4 dimensions, viz. concern, curiosity, confidence and consultation. For example: 'I have so many interests that it is hard to choose just one occupation', 'Choosing a job is something that I do on my own', 'I don't seem to be very concerned about my future occupation', and 'I don't know how to go about getting into the kind of work I want to do'.

In order to validate the instrument further, a pilot test was carried out $(n=30)$. The Cronbach alpha test results revealed good internal consistency, with the alpha coefficient of 0.921 for self-efficacy, 0.919 for career maturity, and 0.727 for volunteering engagement.

\section{Results}

A total of 400 young leaders participated in this study. Table 1 shows there were $143(35.8 \%)$ males and 257 (64.3\%) females, with the majority 368 (92.0\%) being Malay, while 12 (3.0\%) were Indian, and 20 (5.0\%) Chinese. With regard to their religious background, the majority of the respondents were Muslims (95\%), while 2.5\% were Buddhists, 1.0\% were Hindus, and 1.5\% Christians. The mean age of the participants was 22.8 years $(S D=5.65)$, with a range of 20 to 25 years.

Table 1: Demographic profile of the respondents $(n=400)$

\begin{tabular}{lcc}
\hline Characteristics & Frequency & Percentage (\%) \\
\hline Gender & 143 & 35.8 \\
Male & 257 & 64.3 \\
Female & & \\
Ethnic & & \\
Malay & 368 & 92.0 \\
Indian & 12 & 3.0 \\
Chinese & 20 & 5.0 \\
Religion & & \\
Islam & 380 & 95.0 \\
Buddhism & 10 & 2.5 \\
Hinduism & 4 & 1.0 \\
Christianity & 6 & 1.5 \\
\hline
\end{tabular}

Table 2 shows that the mean score for volunteer engagement was the highest among the independent variables $(M=4.25, S D=0.42)$. This was followed by the score for the self-efficacy at 4.19 with a standard deviation 0.52 . Scores for career maturity were generally moderate $(M=3.41$, $S D=0.53)$. The findings from this study hence showed that while the majority of respondents had a high level of self-efficacy (83.0\%) and volunteering engagement (91.0\%), they scored only moderately in career maturity $(81.4 \%)$. 
INTERNATIONAL JOURNAL OF ACADEMIC RESEARCH IN BUSINESS AND SOCIAL SCIENCES

Vol. 10, No. 16, Youth and Community Wellbeing: Issues, Challenges and Opportunities for Empowerment V2. 2020, E-ISSN: 2222-6990 @ 2020 HRMARS

Table 2: Mean, median and standard deviation of the variables

\begin{tabular}{lcccc}
\hline Variables & Mean & $\begin{array}{c}\text { Percentage } \\
\text { Median }\end{array}$ & $\begin{array}{c}\text { Standard } \\
\text { Deviation }\end{array}$ & Level \\
\hline Career maturity & 3.41 & 81.4 & 0.53 & Moderate \\
Volunteer engagement & 4.25 & 91.0 & 0.42 & High \\
Self-efficacy & 4.19 & 83.0 & 0.52 & High \\
& & & & \\
\hline
\end{tabular}

\section{Bivariate Correlation (Pearson's r)}

The interrelationships among volunteering engagement, self-efficacy and career maturity were examined using Pearson's product-moment correlation coefficients. Primary analyses were carried out to confirm that there was no violation of the assumptions of normality and linearity. As depicted in Table 3, a positive relationship was found to exist between volunteering engagement and career maturity $(r=.277, p=.001)$ while the second relationship was between self-efficacy and career maturity $(r=.311, p=.001)$.

Table 3: Bivariate correlations among predictors for career maturity

\begin{tabular}{llll}
\hline Variable & Career Maturity & $\begin{array}{l}\text { Volunteer } \\
\text { Engagement }\end{array}$ & $\begin{array}{l}\text { Self- } \\
\text { efficacy }\end{array}$ \\
\hline Career Maturity & 1.000 & & \\
Volunteer Engagement & $0.277^{* *}$ & 1.000 & \\
Self-efficacy & $0.311^{* *}$ & $0.555^{* *}$ & 1.000 \\
\hline
\end{tabular}

** Significant at $p<0.001$ level

The influence of volunteering engagement and self-efficacy on career maturity

The results of the multiple regression analysis, where the contributions to career maturity by the two independent variables, namely volunteer engagement $(\beta=0.151, p<0.001)$ and self-efficacy $(\beta=0.228$, $p<0.001)$, had significant independent effects on the level of career maturity. Volunteer engagement and self-efficacy together explained $11 \%$ of the variance in career maturity among young leaders.

Table 4: Predictors of career maturity among young leaders

\begin{tabular}{|c|c|c|c|c|c|}
\hline \multirow[t]{2}{*}{ Factors } & \multicolumn{2}{|c|}{$\begin{array}{c}\text { Unstandardized } \\
\text { Coefficients }\end{array}$} & \multirow{2}{*}{$\begin{array}{c}\text { Standardized } \\
\text { Coefficients } \\
\text { Beta }\end{array}$} & \multirow[t]{2}{*}{$\mathrm{t}$} & \multirow[t]{2}{*}{ Sig. } \\
\hline & Beta & Std. Error & & & \\
\hline Constant & 2.388 & .152 & & 15.729 & .000 \\
\hline Self-efficacy & .133 & .033 & .228 & 4.007 & .000 \\
\hline $\begin{array}{l}\text { Volunteer } \\
\text { engagement }\end{array}$ & .109 & .041 & .151 & 2.655 & .008 \\
\hline
\end{tabular}




\section{Discussion}

As a stated objective of this study, the hypothesis to be investigated was that volunteering engagement and self-efficacy were associated with career maturity. The analysis indicated that the hypothesis was supported and that the results for the two dimensions showed consistency with past research (Pajares \& Schunk, 2001; Betz and Borgen (2000). According to Hall et al. (2009) and Musick and Wilson (2008), individuals who are involved in volunteering activities have enhanced personal skill development and sense of civic responsibility, have more career choice and are more employable (Clement and Kamau, 2018). In 2017, the Malaysian Ministry of Education, when redesigning Higher Education, once again stressed the importance of volunteerism among students at the university and college-level (Abd Majid et a., 2020). The government encourages student participation in volunteer activities as research has shown that it helps bring about positive traits such as teamwork, soft skills development and time management (Khasanzyanova, 2017). The findings of the study indicated that the majority of the respondents reported that they had a high level of volunteering engagement and self-efficacy. In this study, volunteering engagement referred to the involvement of young leaders with the Supreme Student Council, a very active group in the colleges and university campus. It is in line with the purpose of the colleges to provide opportunities for students to plan, implement and participate in programs to develop personality and leadership skill (Arshad et al., 2019; Hamzah et al., 2016). As mentioned earlier by Super (1957); Crites (1971), career maturity is linked to the acquisition of specific skills in order to make informed career decisions (Crişan, Pavelea and Ghimbuluţ, 2015). Two of the statements agreed to by most of the respondents were: 'I know very much about the requirements of jobs' and 'choosing a job is something that I do on my own'. The findings in this study support those of Savickas and Porfeli (2011) who define the curiosity scale as the extent to which an individual explores the requirements of the jobs of their choice.

\section{Conclusion}

The findings of this study are significant for a number of stakeholders, universities, Ministry of Youth and Sport, Ministry of Education and youth organizations. An example, the university administration could use the results obtained from this study to understand the level of their students' career maturity. It is important that the university management take steps to prepare undergraduates for success in the working world upon graduation and to be leaders of tomorrow. The instrument devised in the study can be used to determine the level of career maturity in relation to volunteering engagement and self-efficacy of all young leaders so that proactive action can be taken where necessary. For example, areas of weakness can be determined and specific programs such as training development could be implemented to improve career maturity of young leaders.

\section{Conflict of interest}

The authors declare that they have no competing interest in conducting this study.

\section{Acknowledgements}

The authors gratefully acknowledge the funding support provided by the Universiti Putra Malaysia (9584600) under the Research Management Centre, Ministry of Education Malaysia (2017-2019). 


\section{References}

Abd Majid, M. Z., Hussin, M., Norman, M. H., \& Kasavan, S. (2020). The employability skills among students of Public Higher Education Institution in Malaysia. Geografia-Malaysian Journal of Society and Space, 16(1): 36-45.

Allison, C. J., \& Cossette, M. (2007). Three theories of career development and choice. Retrieved March 30 from www.stemrecruiting.org/docs/pub/3theories/pdf.

Arshad, M. M., Ismail, I. A., Nawi, N. R. C., \& Khan, N. K. N. (2019). Promoting Developmental Assets in Positive Youth Development: Identity Development Process through Youth Leadership Mentoring in Malaysia. International Journal of Academic Research in Business and Social Sciences, 9(11): 1462-1480.

Bandura, A. (2010). Self-efficacy. The Corsini encyclopedia of psychology, 1-3.

Bandura, A. (1993). Perceived self-efficacy in cognitive development and functioning. Educational Psychologist, 28(2): 117-148.

Bandura, A. (1986). Social foundations of thought and action: A social cognitive theory. Englewood Cliffs, NJ: Prentice Hall.

Beauchamp, H., \& Kiewra, K. R. (2004). Assessment of career maturity and self-advocacy skills. In E. M. Levinson (Ed.), Transition from school to post- school life for individuals with disabilities: Assessment from an education and school psychological perspective. Springfield, IL: Charles C. Thomas Publisher.

Bernard-Phera, M. J., \& De Bruin, G. P. (2002). Confirmatory factor analysis of the career development questionnaire and the career decision-making self-efficacy scale for South African high school students. SA Journal of Industrial Psychology, 28(2): 1-6.

Betz, N. E., \& Borgen, F. H. (2000). The future of career assessment: Integrating vocational interests with self-efficacy and personal styles. Journal of Career Assessment, 8(4): 329-338.

Birol, C., \& Kıralp, Y. (2010). A comparative analysis of the career maturity level and career indecision of the first grade high school students. Procedia-Social and Behavioral Sciences, 5: 2359-2365.

Blau, P. M. (1964). Exchange and Power in Social Life. New York: Wiley.

Bozgeyikli, H., Eroglu, S. E., \& Hamurcu, H. (2009). Career decision making self-efficacy, career maturity and socioeconomic status with Turkish youth. Education Sciences and Psychology, (1): $15-24$.

Broadbent, J. (2016). Academic success is about self-efficacy rather than frequency of use of the learning management system. Australasian Journal of Educational Technology, 32(4): 38-49.

Brown, E., \& Ferris, J. M. (2007). Social capital and philanthropy: An analysis of the impact of social capital on individual giving and volunteering. Nonprofit and voluntary sector quarterly, 36(1): 85-99.

Caldwell, C., and Hayes, L.A. (2016), Self-efficacy and self-awareness: moral insights to increased leader effectiveness, Journal of Management Development, 35(9): 1163-1173.

Clements, A. J., \& Kamau, C. (2018). Understanding students' motivation towards proactive career behaviours through goal-setting theory and the job demands-resources model. Studies in Higher Education, 43(12): 2279-2293.

Coertse, S., \& Schepers, J. M. (2004). Some personality and cognitive correlates of career maturity. SA Journal of Industrial Psychology, 30(2): 56-73. 
INTERNATIONAL JOURNAL OF ACADEMIC RESEARCH IN BUSINESS AND SOCIAL SCIENCES

Vol. 10, No. 16, Youth and Community Wellbeing: Issues, Challenges and Opportunities for Empowerment V2. 2020, E-ISSN: 2222-6990 @) 2020 HRMARS

Crebert, G., Bates, M., Bell, B., Patrick, C. J., \& Cragnolini, V. (2004). Developing generic skills at university, during work placement and in employment: graduates' perceptions. Higher Education Research \& Development, 23(2): 147-165.

Crişan, C., Pavelea, A., \& Ghimbuluţ, O. (2015). A need assessment on students' career guidance. Procedia-Social and Behavioral Sciences, 180: 1022-1029.

Crites, J. O. (1971). The maturity of vocational attitudes in adolescence. Washington, DC: American Personnel and Guidance Association

Crites, J. O., \& Savickas, M. L. (1995). Career Maturity Inventory. Monterey, CA: McGraw-Hill.

De Raaf, S., Dowie, M., \& Vincent, C. (2009). Improving career decision making of young workers: Design of a randomized experiment. Retrieved May 28, 2019, from http://www.srdc.org/uploads/careermotion_design_rpt.pdf.

Eley, D. (2003). Perceptions of and reflections on volunteering: The impact of community service on citizenships in students. Voluntary Action, 5(3): 27-46.

Emerson, R. M. (1976). Social exchange theory. Annual review of sociology, 2(1): 335-362.

Flouri, E., \& Buchanan, A. (2002). The role of work-related skills and career role models in adolescent career maturity. The Career Development Quarterly, 51(1): 36-43.

Forbes, K. F., \& Zampelli, E. M. (2014). Volunteerism: The influences of social, religious, and human capital. Nonprofit and Voluntary Sector Quarterly, 43(2): 227-253.

Erickson, G. A., \& Noonan, P. (2016). College and career competency (CCC) framework needs assessment. Lawrence, KS: University of Kansas, Center for Research on Learning. Retrieved 1

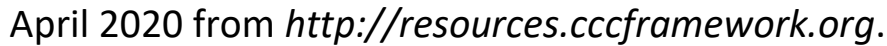

Hall, M., Lasby, D., Ayer, S., \& Gibbons, W. (2009). Caring Canadians, involved Canadians: Highlights from the 2007 Canada Survey of Giving, Volunteering and Participating. Ottawa, ON: Statistics Canada.

Hamzah, S. R. A., Suandi, T., Shah, J. A., Ismail, I. A., \& Hamzah, A. (2016). Understanding the reasons for Malaysian youth participation in volunteering activities. Athens Journal of Social Sciences, 3(1): 39-51.

Handy, F., Hustinx, L., Kang, C., Cnaan, R. A., Brudney, J. L., Haski-Leventhal, D., Holmes, K., Meijs, L.C.P.M., Pessi, A. B., Ranade, B., Yamauchi, N., Zrinscak, S. (2010). A cross-cultural examination of student volunteering: Is it all about résumé building? Nonprofit and Voluntary Sector Quarterly, 39 (3): 498-523.

Harlow, A. J., \& Bowman, S. L. (2016). Examining the career decision self-efficacy and career maturity of community college and first-generation students. Journal of Career Development, 43(6): 512-525.

Holdsworth, C. (2010). Why volunteer? Understanding motivations for student volunteering. British Journal of Educational Studies, 58(4): 421-437.

Khasanzyanova, A. (2017). How volunteering helps students to develop soft skills. International Review of Education, 63(3): 363-379.

Marta, E., \& Pozzi, M. (2008). Young people and volunteerism: A model of sustained volunteerism during the transition to adulthood. Journal of Adult Development, 15(1): 35-46.

McKenzie, S., Coldwell-Neilson, J., and Palmer, S. (2018), Understanding the career development and employability of information technology students, Journal of Applied Research in Higher Education, 10(4): 456-468. . 
Mcnamara, T. K., \& Gonzales, E. (2011) Volunteer transitions among older adults: the role of human, social, and cultural capital in later life. Journal of Gerontology Series B - Psychological Sciences and Social Sciences, 66(4): 490-501.

Miller, K. D., Schleien, S. J., Rider, C., Hall, C., Roche, M., \& Worsley, J. (2002). Inclusive volunteering: Benefits to participants and community. Therapeutic Recreation Journal, 36(3): 247-259.

Musick, M. A., \& Wilson, J. (2008). Volunteers: A social profile. Bloomington, IN: Indiana University Press. NCCPE. (n.d.). Research synthesis: Student volunteering background, policy and context. London: National Co-ordinating Centre for Public Engagement.

Pajares, F., \& Johnson, M. J. (1996). Self-efficacy beliefs and the writing performance of entering high school students. Psychology in the Schools, 33(2): 163-175.

Pajares, F., \& Schunk, D. H. (2001). Self-beliefs and school success: Self-efficacy, self-concept, and school achievement. In R. J. Riding \& S. G. Rayner (Eds.), Self-perception (pp. 239-265). Westport, CT: Ablex.

Patton, W., \& Creed, P. A. (2001). Developmental issues in career maturity and career decision status. The Career Development Quarterly, 49(4): 336-351.

Raty, H., Komulainen, K., Harvorsén, C., Nieminen, A., \& Korhonen, M. (2018). University students' perceptions of their 'ability selves' and employability: a pilot study. Nordic Journal of Studies in Educational Policy, 4(2): 107-115.

Reamon, S. (2016). Managing volunteers: recruitment, retention, and relationship building. SPNHA Review, 12(1): 74-95.

Savickas, M. L., \& Porfeli, E. J. (2011). Revision of the career maturity inventory: The adaptability form. Journal of Career Assessment, 19(4): 355-374.

Shantz, A., Saksida, T., \& Alfes, K. (2014). Dedicating time to volunteering: Values, engagement, and commitment to beneficiaries. Applied Psychology, 63(4): 671-697.

Shier, M. L., Larsen-Halikowski, J., \& Gouthro, S. (2020). Characteristics of volunteer motivation to mentor youth. Children and Youth Services Review, 111, 104885.

Singh, P. K., \& Shukla, R. P. (2016). Relationship between Career Maturity and Self-Efficacy among Male and Female Senior Secondary Students. MIER Journal of Educational Studies, Trends and Practices, 5(2): 164-179.

Raba'ah, S. H., Suandi, T., Hamzah, A. H. (2016). Malaysian Youth Volunteerism Index. Serdang: Universiti Putra Malaysia.

Smith, K., Holmes, K., Haski-Leventhal, D., Cnaan, R. A., Handy, F., \& Brudney, J. L. (2010). Motivations and benefits of student volunteering: comparing regular, occasional, and non-volunteers in five countries. Canadian journal of nonprofit and social economy research, 1(1): 65-81.

Stukas, J. A. A., Clary, E. G., \& Snyder, M. (1999). Service learning: Who benefits and why. Social Policy Report, 13(4): 1-23.

Stukas, A. A., Snyder, M., \& Clary, E. G. (2016). Understanding and encouraging volunteerism and community involvement. The Journal of social psychology, 156(3): 243-255.

Super, D. E. (1957). The psychology of careers. New York, NY: Harper \& Row.

Super, D. E. (1977). Vocational maturity in mid-career. Vocational Guidance Quarterly, 25(4): 294302.

Triantafyllia, K., \& Katerina, S. (2015). Women, Motherhood and Work: An Interdisciplinary Approach. Multilingual Academic Journal of Education and Social Sciences, 3(1), 24-42. 
Tang, K. N. (2019). Beyond Employability: Embedding Soft Skills in Higher Education. Turkish Online Journal of Educational Technology-TOJET, 18(2): 1-9.

Wilson, J. (2000). Volunteering. Annual review of sociology, 26(1): 215-240.

Wollbaeck, D., Selle, P. (2002). Does participation in voluntary associations contribute to social capital? The impact of intensity, scope, and type. Nonprofit and Voluntary Sector Quarterly, 3: 32-61.

Woolfolk, A. (2007). Educational Psychology. 10th edition. New York: Allyn \& Bacon.

Zhu, Y. (2012). A review of social exchange relationship. Studies in Sociology of Science, 3(3): 57-61. 